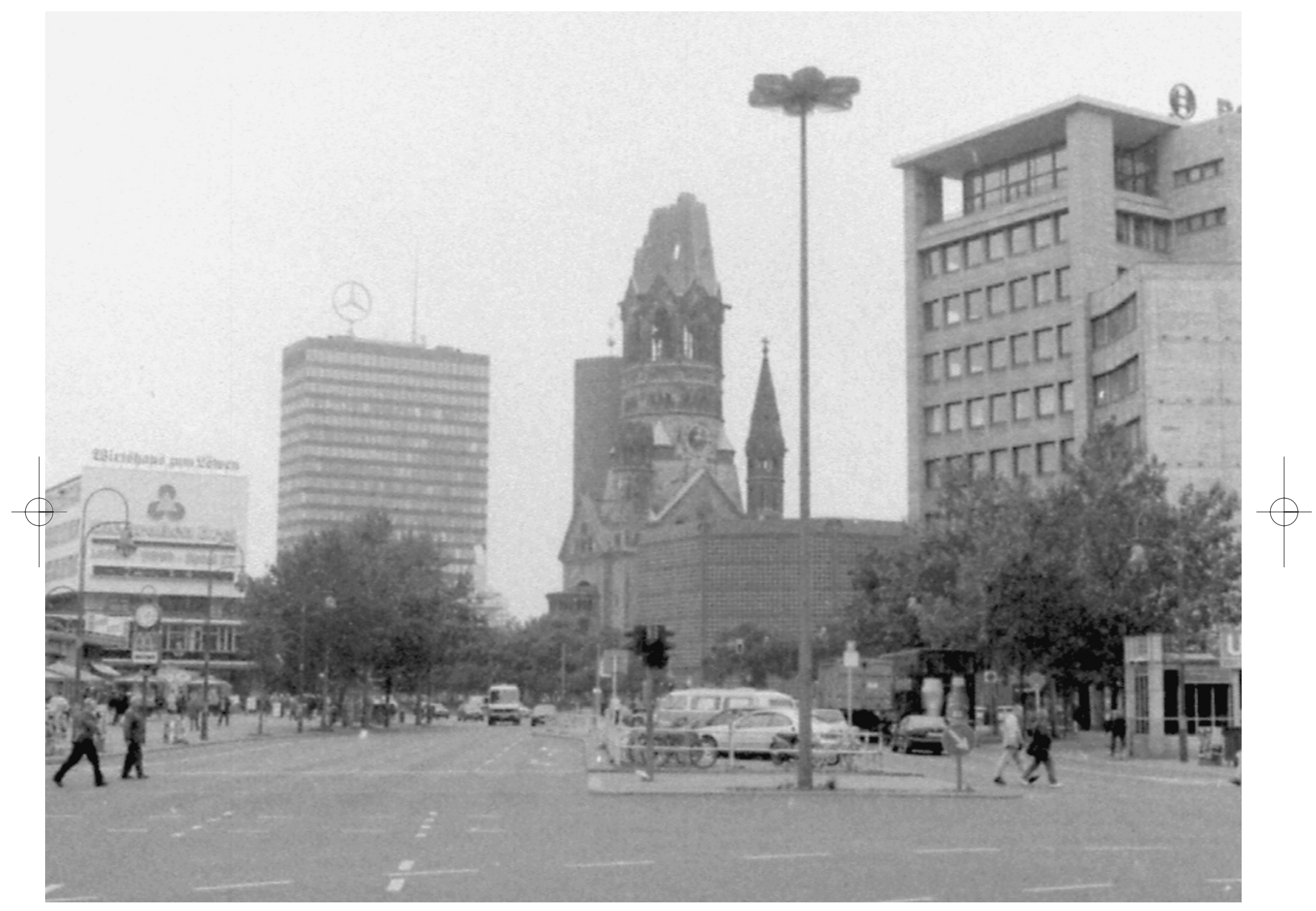

Kaiser Wilhelm Gedächtniskirche and Europa Centre. Once a symbol of West Berlin, the

Europa Centre and the Kaiser Wilhelm Memorial Church are situated at the northeast end of the Kurfürstendamm, a street renowned for glamorous shopping opportunities. All photographs in this article are by the author 


\title{
Empty Space and the City: The Reoccupation of Berlin
}

\author{
John Grech
}

One of the central points Lewis Mumford makes in his classic study The City in History is that, historically, cities are places where more and more people have gone to realize their lives. ${ }^{1}$ This article deals with cities; in particular, it deals with the city of Berlin, or should I say, with a portrait of that city, a city that lies at the heart of many events marking the development of the West in its current form. This work takes as its central themes the emptiness and space in the city created by the Berlin Wall. I develop these ideas in the form of a meditation, an essay in the tradition of Montaigne, a personal reflection on a theme, that more than documents the transformations of the city from the 1980 s to the 1990s. It is also a travelogue. Thus this article transcribes spaces geographic, economic, political, cinematic, personal, and linguistic on an ambling sojourn from Potsdamerplatz to the Reichstag.

The impressions and speaking positions given here are those of a Maltese Australian who has spent much of his life in the heart of Sydney, and who has traveled to Berlin occasionally. This is the position of a misplaced individual who stands both here and there, on the margins, a migrant and a tourist. The present essay considers these positions, the migrant and the tourist, alongside that of the citizen in an analytical synthesis examining how "the people" occupy space in "the city" today.

I might have titled this essay "Sydney/Berlin: Center/Periphery," but such a name might have suggested an anachronistic exploration that travels from center to

Radical History Review

Issue 83 (spring 2002): 115-42

Copyright 2002 by John Grech 
edge along two big cities at the end of the twentieth century. In fact, I want to displace fixed notions of time-space, here-there, past-present, in-out as part of a larger, ongoing search for a sense of belonging. Today, places like Sydney and Berlin form part of a global web of habitable spaces emerging in the city of the twenty-first century.

Yet if Sydney and Berlin constitute explicit nodes in this network, places like Malta and Amsterdam remain implicitly available as places where cohabitation and belonging may become more actual, that is, places where both the symbolic and material occupation of space may be accommodated more satisfactorily. While I never fully explicate these places in this article, they exist within my work nonetheless.

This essay presents a range of sources. Two films by Wim Wenders-Wings of Desire (1987) and Faraway, So Close! (1993) — are central to formulating an initial impression of Berlin. A selection of writings and my own work as an artist and writer accompany these two sources. In this way, I seek to establish an intersubjective text that does not claim a singular authorial voice over either the places evoked or the texts referred to. What I hope to do is open up a third space-for the reader - that we may coinhabit. Projects like this also always address difference and identification, integration and exclusion, a desire to participate and contribute, as well as a need to be honored and recognized.

I have structured this article into three parts. Part 1 talks about Cold War Berlin, in particular the sense of space created east and west of the city. Part 2 deals with the reoccupation of the city during the 1990s, first by looking at how capitalist enterprises took up a place in Berlin, and then by looking at the role language plays in the demarcation and capturing of space. I have created two intersections between parts 1 and 2 that discuss the disappearing/reappearing subject.

The communicative strategy behind this essay seeks to create a dynamic relationship between the different roles and parts found therein, an approach that will prove quite demanding of you, its receiver, too. If you seek to measure the success of this strategy, you might like to ask if there is a space, or a sense of space, a manifestation, that emerges (or not) for you to enter and speculate. We can decide if we can cohabit later. 


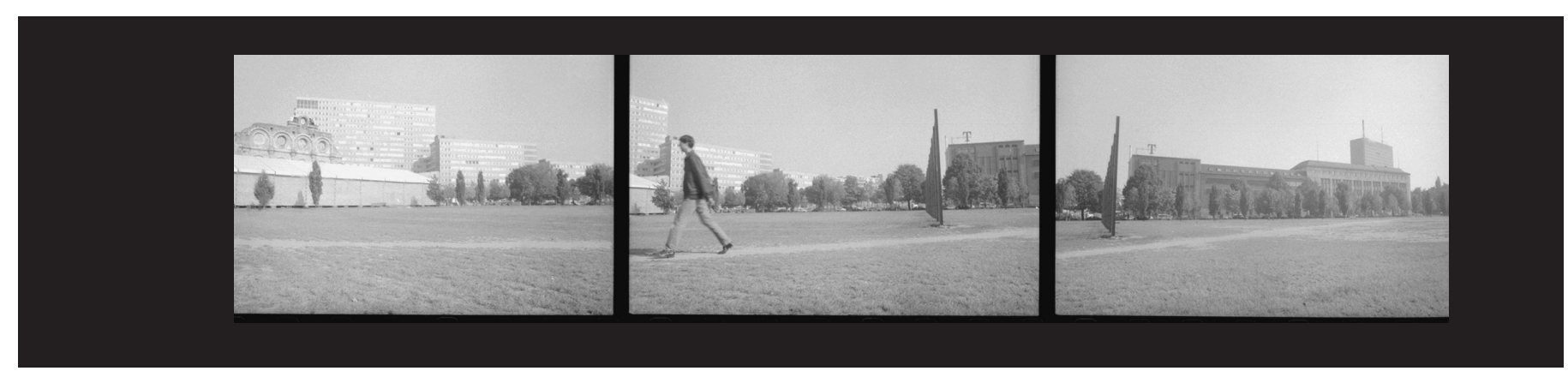

Triptych of park near the ruined Anhalter Bahnhoff. Wim Wenders shot several scenes for Wings of Desire at this site, including one where Peter Falk goes for a walk through Berlin in search of his German roots.

\section{Part 1}

Arrival

I was a latecomer to Berlin, having only arrived in the city for the first time in 1995 . A year earlier, Wim Wenders's Faraway, So Close! the second of his angels in Berlin films, had captured my imagination. Before that, Berlin figured only as a shadow in my mind, cast long ago when I was just a boy growing up on a sunny island in the middle of the Mediterranean. Berlin! Berlin? That was the shadow of the Cold War. But today, Berlin is different.

One of the things that struck me in my first real encounter with Berlin was its similarity to Sydney. No, I do not mean that sunny skies and blue waters surround it, as they do Sydney. Rather, it was the seeming omnipresence of building sites, cranes, and proposed construction projects. The sense of history, however, marks one important distinction between Sydney and Berlin. If we can characterize Sydney as a city with too short a memory, a city that can't or won't remember, or a city that forgets too easily, Berlin, we could say, has a memory too long, inescapable, unbearable.

But today, it might also be said, Berlin is trying to change that image, attempting to recapture its tenor of the 1920 s rather than that of the 1980 os. With much hubbub, the streets are again pulsing like the veins of a wildly excited animal, intoxicated by diesel fumes. ${ }^{2}$ The city pumps like someone working out to the pulsing, driving tune of construction engines and jackhammers. This is the New Republic, and the glory days of the Weimar period might yet be recuperated - although no one would daresay that in so many words. Berliners remain mindful of the lessons of history. 


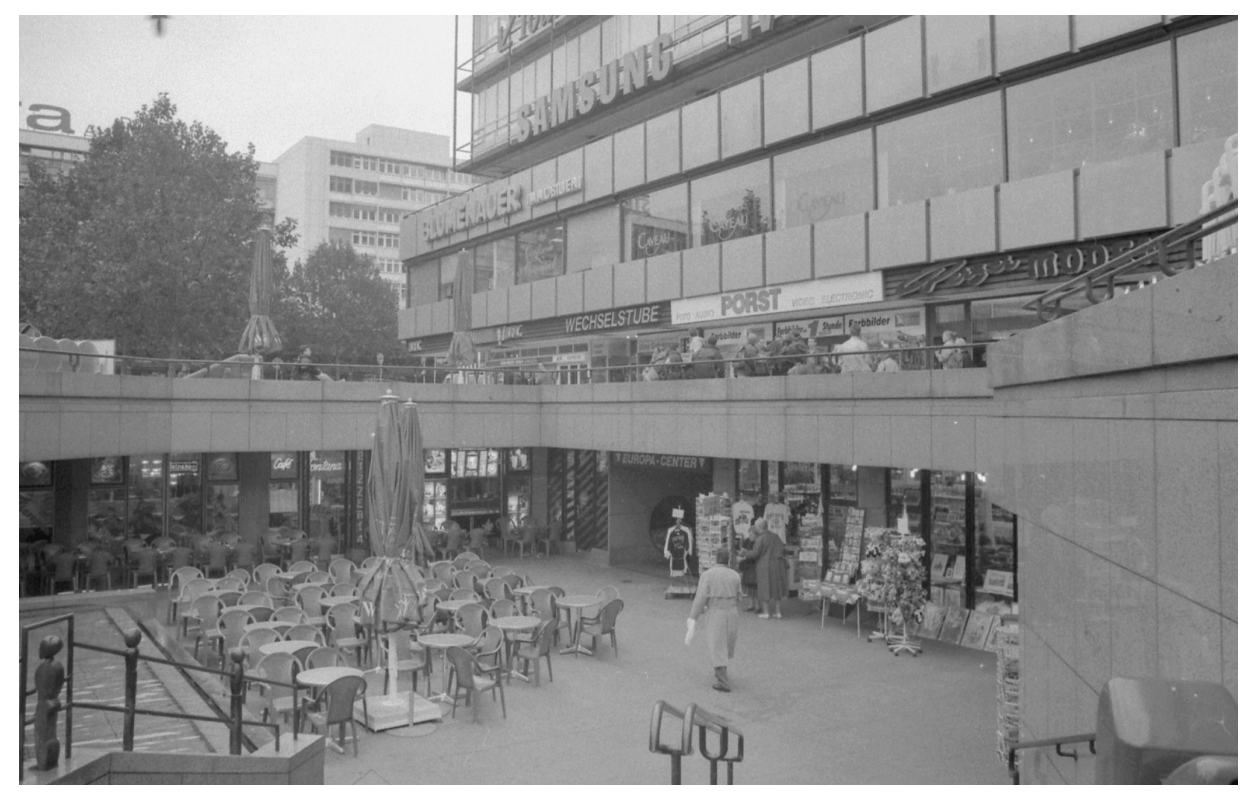

Europa Centre Shopping Plaza. Arcades like this were legendary in the East as word of the profusion of Western consumer goods permeated through the Berlin Wall.

\section{The Cold War City}

Before entering the city of the present, I want to recall what Berlin may have been like during the Cold War. Not having witnessed that city myself, I have relied on the interpretations of others to draw and write from. ${ }^{3}$ One such source, Karen Jaehne, in reviewing Wim Wenders's Wings of Desire, wrote that "today Berlin . . . is kept as tarted up as Macy's Christmas window, a virtual display case of the virtues of capitalism dead centre in the Eastern Bloc."4 Alexandra Richie reiterated this impression in her recently published history of Berlin, where she suggested that, "West Berlin was transformed . . . after the success of the Allied Airlift in 1948-49 . . into a 'Showcase of Capitalism' meant to prove the superiority of the West and to dazzle those in the Soviet zone." 5

Long before the end of the Cold War, the promises of capitalism already primed contemporary life in this thoroughly postmodern city. ${ }^{6}$ Shopping arcades such as the one at the base of the Europa Centre had long become legendary in the East as word of the profusion of Western consumer goods passed over the Berlin Wall. In some parts of Berlin at least, West Germans were thoroughly caught up in postindustrial modes of production-commodification and consumption, the open market, and money. Not all West Germans, many of whom realized what was happening before their eyes, embraced this situation. According to Markus Wolf, West German business millionaire Hannsheinz Porst, for example, "believed that the [GDR's] socialist system, particularly its welfare system and its anti-fascist tradition, represented a worthy alternative to West German capitalism."7 


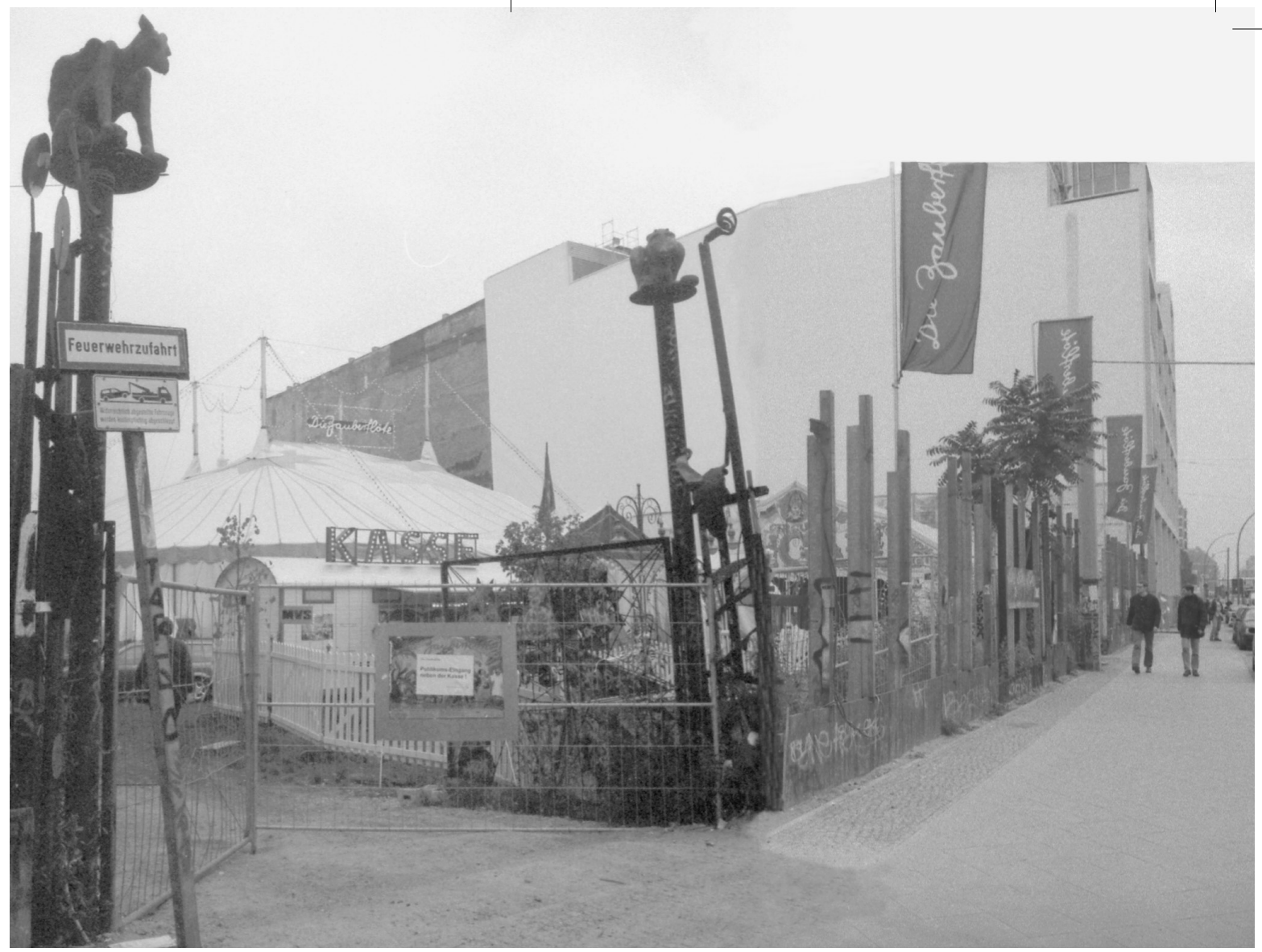

The space where Wenders placed the circus while shooting Wings of Desire in the 1980 s might be gone, but there was still some room for the circus in Friedrichstrasse in 1998.

That is how some writers saw Berlin during the Cold War. I will return to consider how capitalism continues to shape the city later.

\section{The Cinematic City}

Another picture, or set of pictures, of the Cold War city comes from films. One movie, Berlin Cinema (dir. Samira Gloor-Fadel, 1999), featured Wenders as well as another prominent European filmmaker, Jean-Luc Goddard. In this film, Wenders reiterated his point from the 1992 Berlin Forum where he commented on his appreciation of Berlin's sense of space. He spoke about space in reference to his filmsthe sort of in-between space that gives audiences room to fill them with something of their own making, their own meaning. ${ }^{8}$

Drawing on his experience of filming Wings of Desire, Wenders recalled Berlin in the 1980 os. He stated: "There are innumerable gaps all over the city, with walls that do not exist in other cities, so that there are these empty . . . unoccupied places in between . . . barren land, derelict land, even in the inner city areas, ... places where nothing happens. ... There used to be a place in Berlin where we put a circus for a film."9 Turning to the question of how the future capital of Germany was to be reconstituted - remember that the forum took place in 1992-other speakers emphatically agreed with Wenders on the importance of retaining this sense of space. Jacques Derrida, another participant, suggested: 
a city has to remain ... open not only to aliens, but as a place for hospitality in the future. . . . it's not simply the physical occupation of space. . . . openness has to do with a dimension of symbolic, linguistic possibilities. . . . The city I would like to live in is a city I could easily leave. . . . That's why I insisted on the principle of leaving the openness of the city. ${ }^{10}$

I will come back to the idea of symbolic and linguistic possibilities later, but first I want to continue examining the notion of space in Berlin in the 1980 .

\section{Space}

Turning to the east of the Cold War city, Brian Ladd characterized the Berlin Wall as an interstice where nothing happens, a division that reveals everything. ${ }^{11}$ Ladd suggests the most remarkable feature of the Soviet security system was the silence and openness it created. This empty zone of nothingness was where the East attempted to cordon off the West and secure the survival of the communist regime by silencing opposition, clearing out pockets of resistance, and freezing all movement. The German Democratic Republic's solution to the seductive lure of the West was to try to shut it out of the minds of the people. Empty, silent space. ...

Cracks in the Wall near the Gedenkstätte Berliner Mauer. A photoreconstruction of the space between the East and West created by the Berlin Wall. Graffitied critiques of the East were a celebrated feature of the freedom of West Berlin.

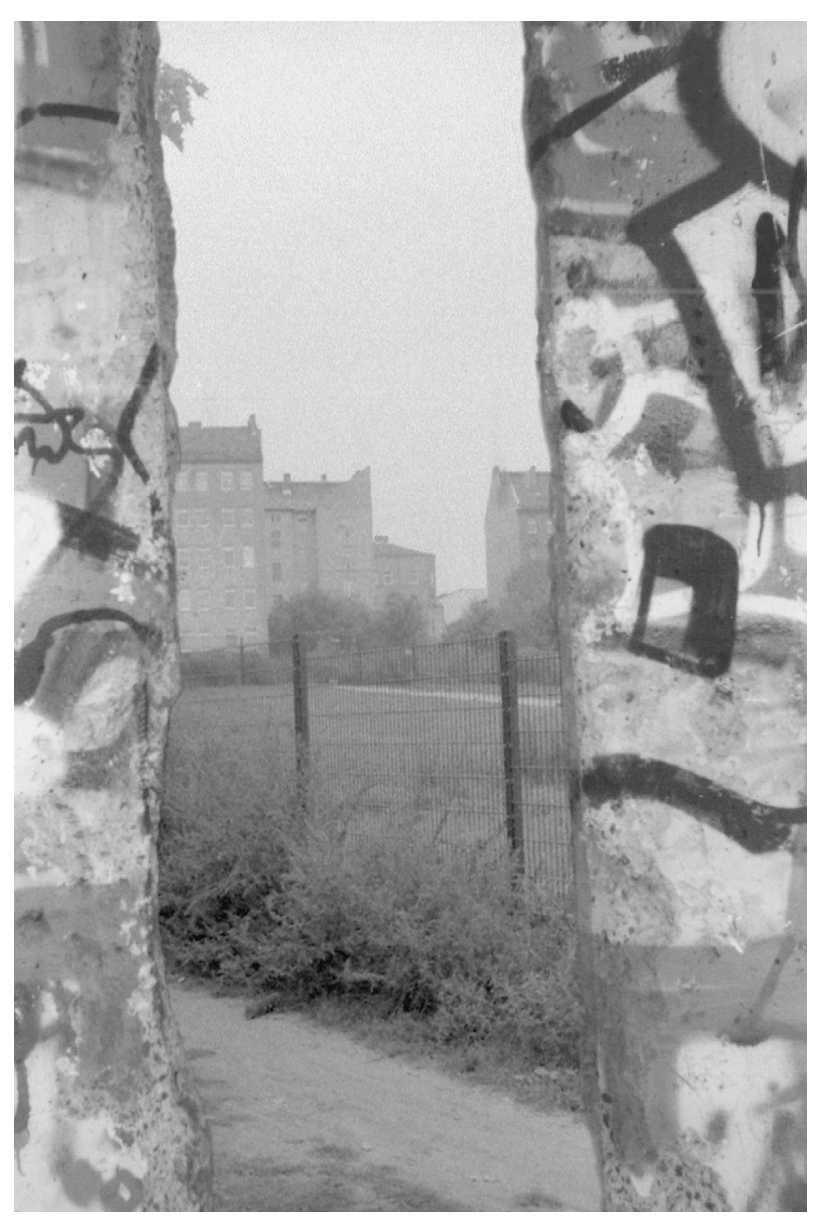




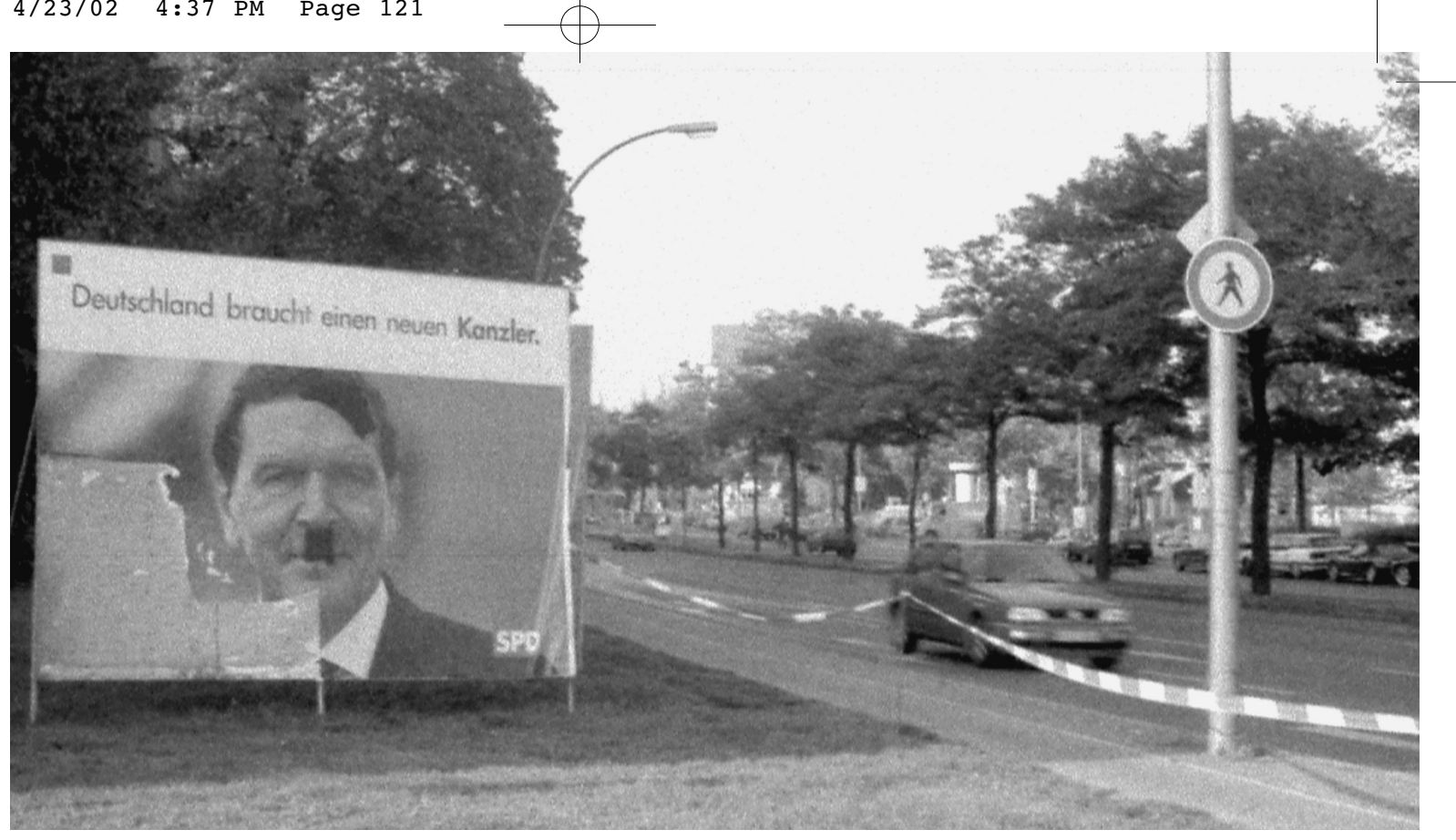

A graffitied poster of Gerhardt Schroeder during the 1998 German election campaign. The Social Democrats finally beat Helmut Kohl's Christian Democrats after more than a decade in opposition. One of the factors behind Kohl's loss was increasing disillusionment among former East German electors, who abandoned the Christian Democrats and delivered a significant vote to a reformed Communist Party.

Yet Berliners did not long to shut out consumer goods or capitalist shop fronts. History has given Berlin an unusual legacy, though it is not a legacy that the city remembers loudly, or proudly, even today. As a visit to the Kaiser Wilhelm Gedächtniskirche highlights, it is a history of shame and darkness that renders those sensitive to the fullness and depth of its meaning silent, perhaps even desperate. The graffitied critiques (of the East), a celebrated feature of the western side of the Berlin Wall, as a visible yet silent reminder some Germans felt compelled to make concerning the deeds of the totalitarian state.

So, what is this empty, silent space really about? How can people "work off" the legacy of the past, either fascist or communist, as Jürgen Habermas keeps insisting they should do?12 Is it possible, as the rulers of the former East Germany tried to do, to stave off the totalitarian tendency lurking in the human mind that realized such "topographies of terror"-left and right - through the creation of an empty, silent space, an area in between?13 Or is it better to cover it over with something new altogether, obliterating the past?

Let us now recall that for Erich Honecker and his fellow communists, the Berlin Wall was actually and always intended to be an "antifascist protective rampart."14 According to GDR authorities, the Mauer served to protect the East against the influence of the Nazis whom the West had so willingly recuperated after World War II. The Wall constituted something like a condom, then, a device that allowed the East to stay in bed with the enemy while protecting itself from its opponent's disease. For the paternalistic leaders of the East, space was about protection, a buffer zone to keep the howling Cold War wolf, or should I say traveling salesman, away from the door. 


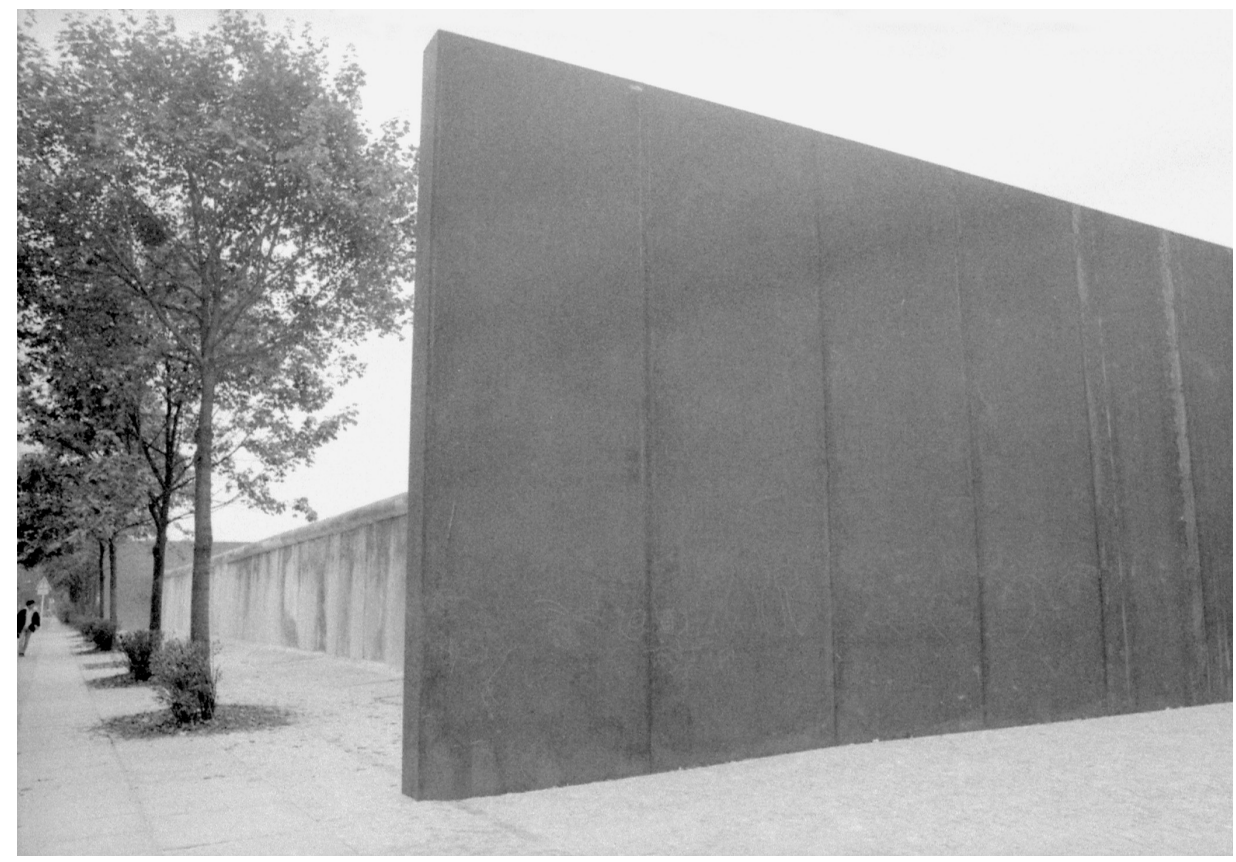

The Gedenkstätte Berliner Mauer stands in memory of those who died trying to escape from East Berlin during the Cold War.

\section{Silence}

With the benefit of hindsight, however, it would appear that the wall actually created a gaping hole that the West obligingly filled. As Dick Hebdige pointed out in a travelogue called "Guilt Trips," the Allies filled the interstice with the voice of President Kennedy, the sounds of Pink Floyd, and (again) the advertising glitter of an endless array of consumer goods broadcast on radio and television waves. 15 The West, so apparently unlike the East, celebrated activity, exchanges, and flows by encouraging divergence and embracing difference. In spite of all the walls and barriers, silence and empty space, nothing could stop the advertisers' jingles from permeating the people's very heart - their living rooms — that sanctity that is their lebensraum, filling it up with unending desires for consumer goods and the unfaithful promises of satisfaction.

By the end of the space race, and certainly by the beginning of Star Wars, not long before the end of the Cold War, the West had completely succeeded in presenting itself as the state of freedom - the freedom to move and fill in empty space. There was even room for dissidents, artists, and intellectuals among the space 
invaders, room to mark out difference, utter critiques, and speak, like a conscience to the self, for and on behalf of every other.

Unfortunately for the communists, the potential danger of being filled constitutes one of the most significant features about empty, silent space. Furthermore, the course of events since the collapse of the Berlin Wall in 1989 reiterates the fact that, in a capital city also claiming to be a city for capital, space simply cries out for occupation!

In concluding the first part of this essay, we may say that two Cold War cities existed in Berlin, each of them possessed and governed by two distinctive notions, or approaches, to time and space. These may be surmised as follows:

1. East Berlin, which openly preserved a sense of empty, silent space, inherited partly from the legacies of a fascist state and partly from the destruction of war, a space the communists tried to fill with fear. This, the communists hoped, would simultaneously capture and buffer against the traces of a competing capitalist West as well as contain and control the minds of the people;

2. West Berlin, where the Marshall Plan's politics of reeducation sought to quickly eradicate all traces of an authoritarian culture as well as the gaping wounds of war. The plan sought to transform West Berlin into a symbol of economic reconstruction: a young, vibrant, and forward looking city that embodied a feeling of freedom and movement over and above, beyond and through all walls.

The second part of this article looks at how capitalism continued to define the city in the 199os before turning to the role of language in making, filling, and finally erasing space. But first I would like to say a little more about the speaking positions within this essay. 


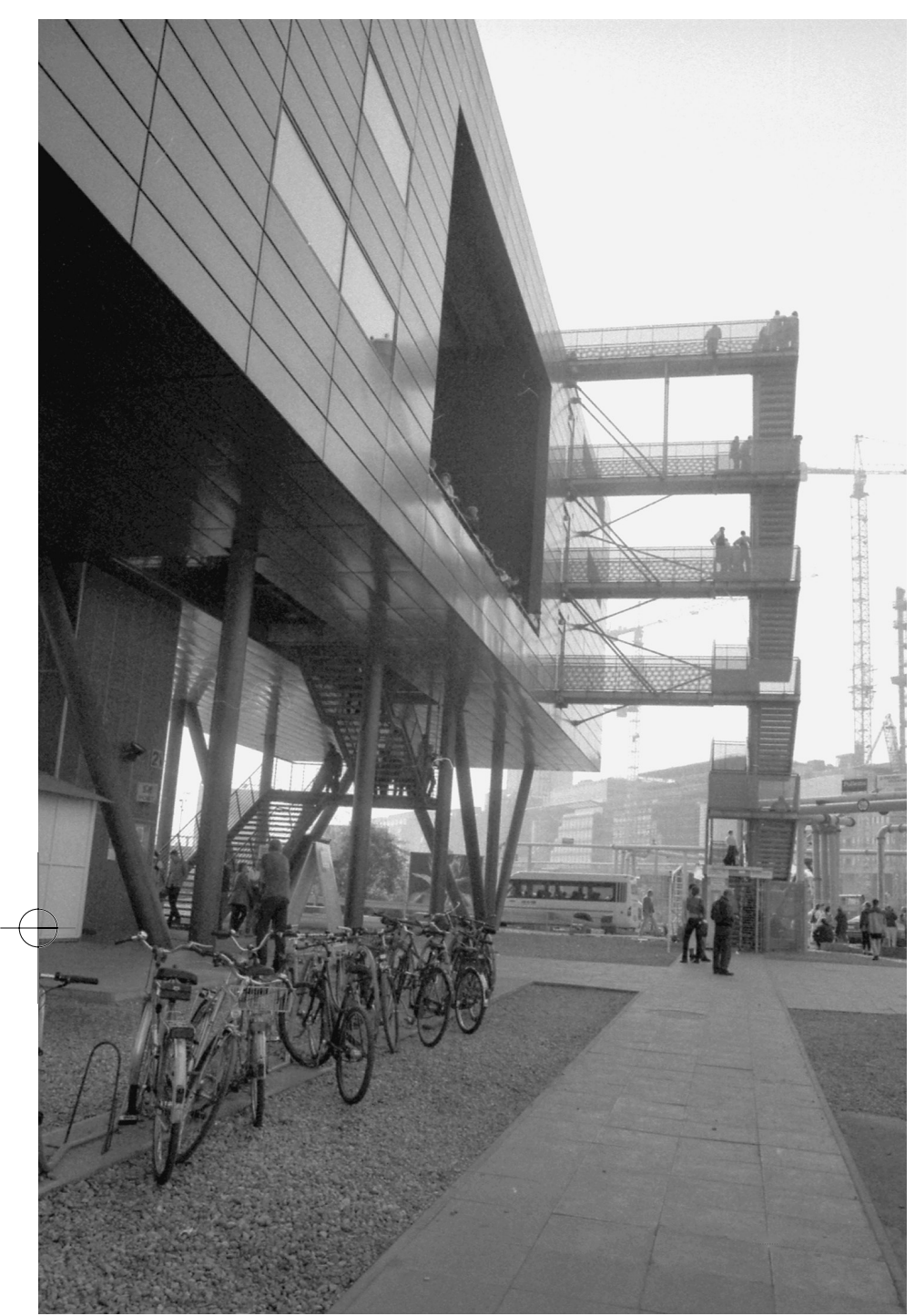

View of the InfoBox in Leipziger Platz, on the edge of the Potsdamerplatz, in 1998 where even the reconstruction of Potsdamer Platz could be commodified and marketed.

\section{Intersection 1}

Tourism

Whenever I go to Berlin, it is usually via Amsterdam, where a stamp placed in my passport tells me the role I am expected to play. Coming from beyond the European Union (EU), I am a tourist, a visitor. The EU, with all its wonderful cities, encourages me to visit and very happily receives me, but only for a while. I can fill a space in this new European citadel, but only temporarily, and only in passing.

In taking up such a space, I am asked to fulfill a particular role, not as participant or producer, but as spectator and consumer. Like the angels in Wenders's movies, I am only allowed to observe and record what I see. But like Damiel in Wings of Desire, I would like to participate, to jump into the stream of life. And like Cassiel in Faraway, So Close!, I'd also like to contribute, to do something good and meaningful, both for myself and for others around me. So, this is what I do.

Idling through the streets, looking, as tourists do, one sees many things: posters, ads, glamorous new buildings, and ambient old ones. In today's booming, tourist-aware city, the look is clean, shiny, sterilized, and efficient. But doing as tourists (are supposed to) do, we not only see, we also buy things such as postcards that we occasionally write and send to friends and family, reflecting on our experiences. We could speak of some of these things as products, or at least by-products, of the tourist's role as observer. 
Yet we should not confuse the contemporary tourist's observations with those of the Classical or Renaissance observer who stands ideally fixed in the absolute time-space of a panoptic God. This tourist, in the manner of de Certeau's pedestrians, remains human, a "walker [who] constitutes [space], in relation to his position, both a near and a far, a here and a there. ... Walking [that] affirms, suspects, tries out, transgresses, respects, etc., the trajectories it 'speaks." 16 This is one of the benefits of being a tourist - you have space to reflect back on where you came from as well as to observe, even consider, what responses, if any, you might like to generate to the places you occupy. All the while, you're marveling at what is all around you.

In looking and walking, as tourists do, we cannot help but make things more than what we see. And, although given no official status, tourists still produce things in addition to eating, sleeping, and consuming — the things we need for our daily sustenance. Ambling on our way, tourists constitute the city in ways that neither the migrant nor the citizen, both too caught up in the busyness of their daily lives, can do.

Terms like alienation and reification have been used to identify experiences like these, where people, as creators or producers of things, are separated from what they make and do. Such terms seek to articulate how autonomous individuals living in the capitalist state are subjected to laws and conventions and by contracts, rights of ownership, title deeds, and citizenship. Such conventions, we might still argue, take what is inalienable in truth from an individual and turn it into a right distributed to some and denied to others. Yet in spite of this, I have produced things out of my visits to Berlin - just as surely as Berlin has produced things in me. The thoughts in this essay serve as examples of some of them, although they are not just my own. Here, I also host other people's thoughts.

\section{Intersection 2}

\section{The Idler}

Susan Sontag has the following to say about a touring photographer: "The photographer is an armed version of the solitary walker, reconnoitering, stalking, cruising the urban inferno, the voyeuristic stroller who discovers the city as a landscape of voluptuous extremes. Adept of the joys of watching, connoisseurs of empathy, the flâneur finds the world picturesque."17 Walter Benjamin's notion of the flâneur is important to my concerns, and Sontag's interpretation adds depth to it by associating the voyeur with the stalker and the reconnoiterer. 18 We see connections here between acts of desire, hunting, and war. But I'm not sure about the relationship between the flâneur and the connoisseur. I cannot quite agree with the sense of distance such a word suggests between the connoisseur and the object of his or her connoisseurship. 


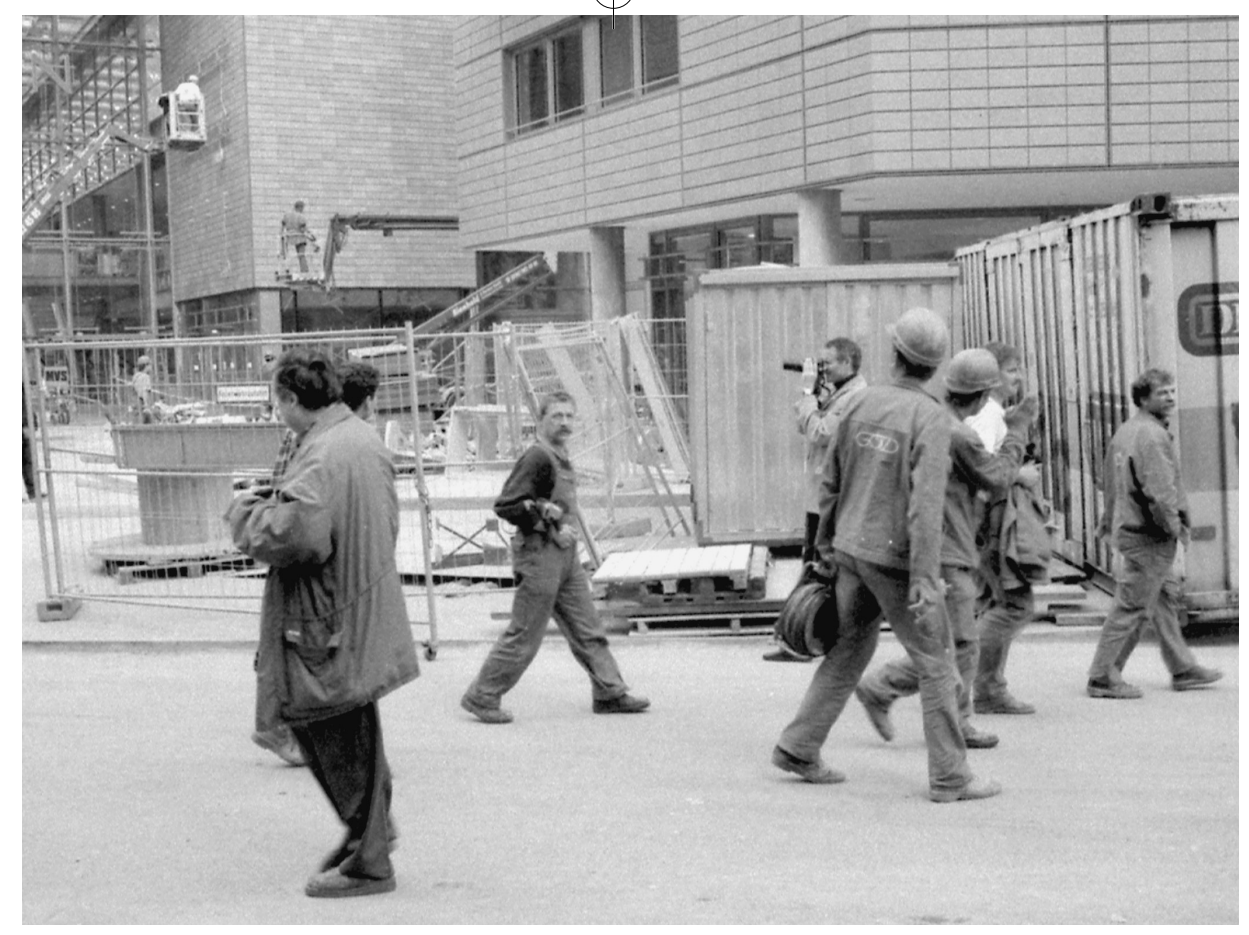

Construction site, Potsdamerplatz, 1998. To the amusement of workers, tourists snapped up one photo opportunity after another as they idled through Potsdamer Platz.

For this makes for one of the strange ironies of today's city. While places like Berlin and Sydney want to impress themselves, their own particular style and regional taste, on tourists, they still seek to provide a sense of the familiar through such things as automatic teller machines (ATMs), which hold us, at least momentarily, in a mythic space that looks and feels so much like home that we feel safe even in the most exotic, far-flung places. These kinds of spaces structure tourists' experiences by repeating acts such as standing in front of ATMs punching buttons to get money - a repetition that collapses new and novel (spatial) encounters back into experiences from previously known places where we can reenact familiar narratives giving us a sense of still being at home.

The paradox in the tourist experience has to do with the limitations placed around us as individuals - as foreigners - while collapsing the distance between us and the places we are in - foreigners in a foreign land. (I will return to this paradox when I discuss the role of language.) As tourists, we go along with this paradox happily, of course, taking photographs as a way of capturing the spectacles of this foreign yet familiar city. In this way, tourists write themselves into the city in the only way they can. Yet, as I walked around Potsdamerplatz, I realized that Berlin has not quite learned "the art of growing old by playing on all its pasts ... [completely successfully, like, say, Rome]. Yet it neither [re-] invents itself, from hour to hour [like Sydney or New York], in the act of throwing away its [past] ... and challenging the future."19

Then I began to wonder what tourists really came to see (or expected to see) in Berlin during the 1990s. Was it the spectacle of a divided Cold War city, an openair museum, and a tyrant's tomb? Was it the specter of economic renewal at Pots- 
damerplatz, like a new Glasgow or Sheffield? Did the attraction come from the transformation of a decaying, underutilized city turning itself into a buzzing, revitalized metropolis, a busy thoroughfare, a freeway for ideas, hopes, and dreams? And what about the empty space? Did anyone other than Derrida, Hebdige, and Ladd come for that?

\section{Part 2}

The City

From the InfoBox in Leipziger Platz, tourists as well as residents of Berlin can observe (mostly itinerant migrant) workers toiling away before their eyes, transforming what was, not all that long ago, the rubbish dump of history back into a throbbing center for commerce and industry. I was somewhat amazed to see people willing to pay for the privilege of looking at a city undergoing this sort of open-heart surgery. Yet, on reflection, I should not have felt all that surprised, for Berlin seems to have an ingenious tradition of developing innovative, original, and sometimes highly aesthetic (not to mention financially rewarding) ways of capturing, repre-

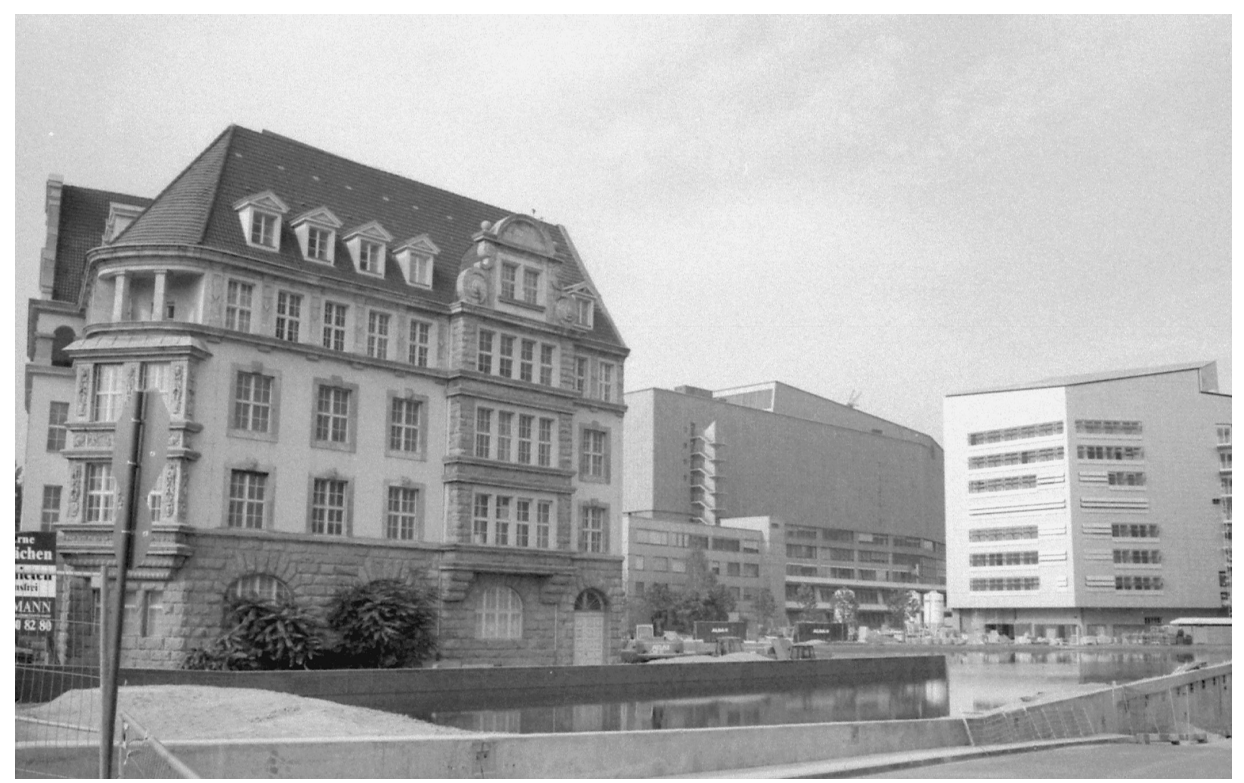

Potsdamerplatz, 1998

senting, and marketing itself. Along the way, the city has fostered, nourished, and inspired many new artistic (and other) movements in the twentieth century. As the InfoBox suggests, even the reconstruction of Potsdamerplatz lends itself to commodification and marketing. 
In spite of these efforts, Berlin remains unable to obliterate its past. Instead, the city clumsily tries to turn even the darkest aspects of its history into saleable items. One of the new tower buildings in Potsdamerplatz graphically demonstrated this. Seemingly determined to preserve the memory of the past, it posted a monumental reproduction in 1998 of a soldier helping an East German citizen to scale the Berlin Wall. As other advertising campaigns have shown, images of liberation, multiculturalism, even the tragedy of AIDS, may serve as marketing tools. I wonder, are we witnessing the same act when Simonedes' re-membered the bodies of the dead inside Scopa's banquet hall in Thessaly?20 That question, along with another that arises, namely, whether the ritual of honoring the dead and the past can be appropriately performed when it becomes commercialized, would be the subject of another paper.

If space, coming back to the theme of this essay, constituted one of the most striking features in Cold War Berlin, the quick occupation of the city's emptiness is equally striking today. If Wenders was right in saying, in what seems now so long ago, that "the Americans have colonised [sic] our subconsciousness," it seems equally true today to say that capitalism has colonized every inch of time and space, in the city as well as in our lives. ${ }^{21}$

In examining the transformations of the city's open space, one is tempted to repeat an observation made all too often-capitalism turns everything to the interests of business. Even the city's own citizens have been turned into consumers, tourists in their own backyards. But this sounds like a cliché today. Besides, one of the things that the end of the Cold War promised was liberation from the tyranny of ideology. As the economic rationalists of the 1980 s had us believe, the marketplace exists without ideological baggage or meaning. Capitalism constitutes a value-free system of free-floating signs without any fixed referents whatsoever.

The problem becomes how we convince those poor souls living in Thatcher's Britain, shunted from one odd job to another, of the fact that they really should not feel "fixed" to the bottom rungs of the economic ladder. ${ }^{22}$

\section{The Citizen}

Economics did not serve as the only motivating force for citizens of Berlin in the late 1980s. The fall of the Berlin Wall gave rise to powerful dreams - dreams that gave people a sense of belonging in a city once their home. By the end of 1989 , it actually looked as though the people were really taking power and claiming the city, finally, as their own, while asking the occupying superpowers to leave.

Back in 1990, the collapse of the Berlin Wall did promise what people longed for: freedom of movement. Destiny and history looked, at last, to have come together over the same time-space. Thus reunited, Germans could finally move toward a universal, pan-European, participatory democracy where citizens could enjoy the freedom of shaping their own lives as well as participate in the shaping of a new state's 


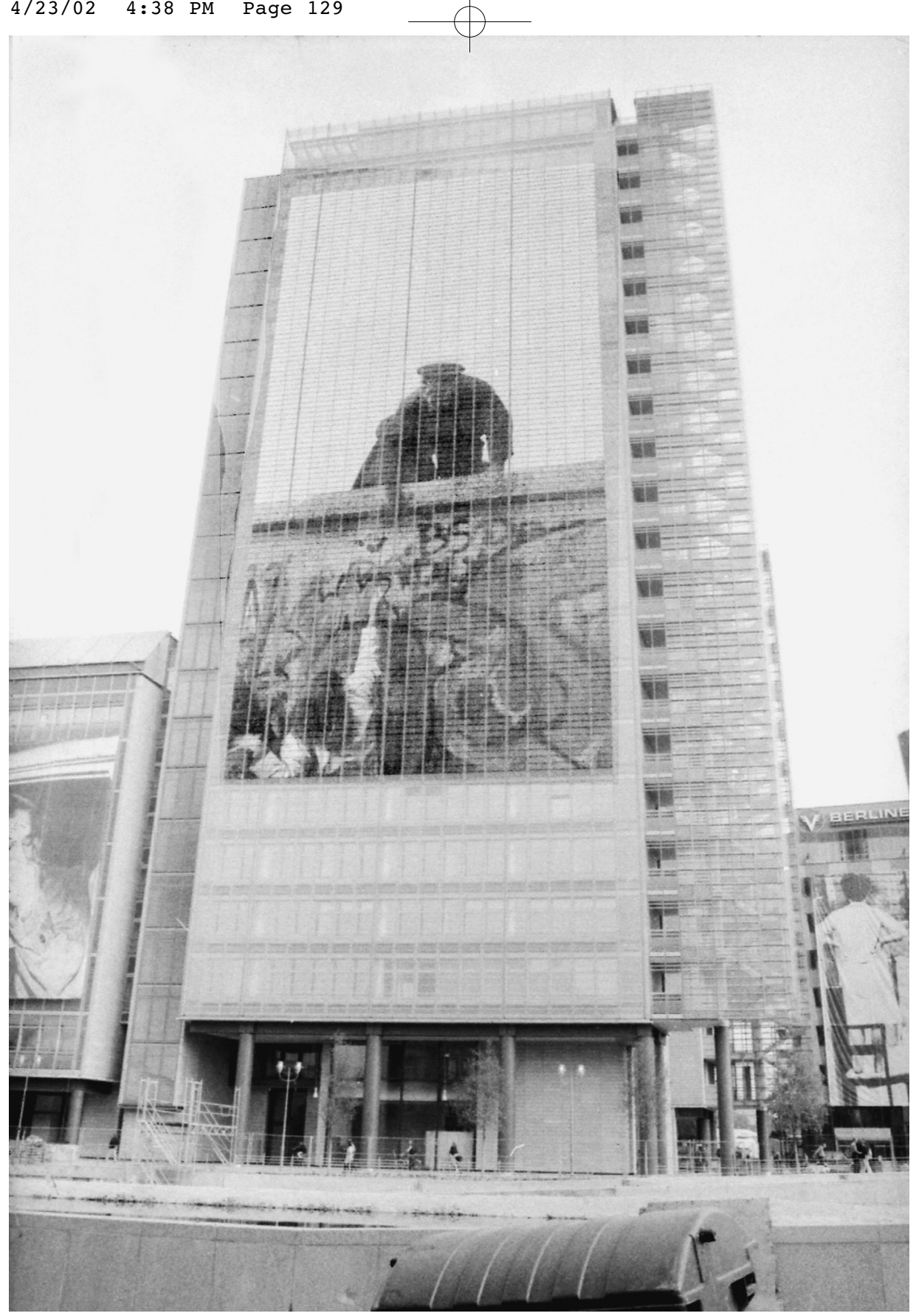

Monumental marketing. This impressive figure of an East German soldier helping a civilian climb over the Berlin Wall in 1989 was placed over the entire facade of this building in Potsdamerplatz. Is this a monument to the liberation of the People or is it now a marketing tool?

future. At last, Berlin had redeemed itself by simultaneously lifting the terrible burden of history and realizing a new, all-inclusive democracy.

Today, however, it appears that the body politic that emerged in 1989 was naive to believe it could really fill the gap created by the collapse of communism. As Howard Caygill soberly suggests, the future of the city already became clear as early 
as November 1989, when the reconstruction of Berlin was being "secretly" prefigured in the leather-clad lounges and wood-paneled interiors of the city's tower blocks and administration buildings. ${ }^{23}$ The reoccupation of Potsdamerplatz stood at the center of those imaginings. Perhaps Homer and his mythical recollections of the 1920 figured not far below the surface of such dreamings. ${ }^{24}$ Then Potsdamerplatz buzzed as people teamed all over the streets, sat in cafés, smoked cigars, and talked excitedly about all sorts of possibilities. In those days, so legend has it, you could buy almost anything in Potsdamerplatz. Was this the pedigree that attracted German as well as multinational corporations to take up residence there? It seems somewhat prophetic, in the light of what has happened, that Wenders put the circus in Wings of Desire at a place called Belle-Alliance Platz. Although that place now goes by the name of Mehringplatz, there is still room for a circus in central Berlin; today it is located in nearby Friedrichstrasse. 25 There it may stay, but, like the circus in Wenders's film, only as long as the belle alliance between money and entertainment is properly maintained. The circus still has to pay the rent.

Caygill concluded, therefore, that the Berlin City Forum, where Wenders, Derrida, and company gathered in the early 1990s, became just another showcase for a "technocratic 'democracy . . . where the people were to be guided by experts. "26 Like the tourist and the migrant, the newly freed citizens of the capital were left standing in the cold.

The artist Christo wanted to wrap the Reichstag as long ago as the 1970s. Finally in 1995, he got the opportunity, and Berliners came out in droves to celebrate the lifting of the black shroud of history from their city.

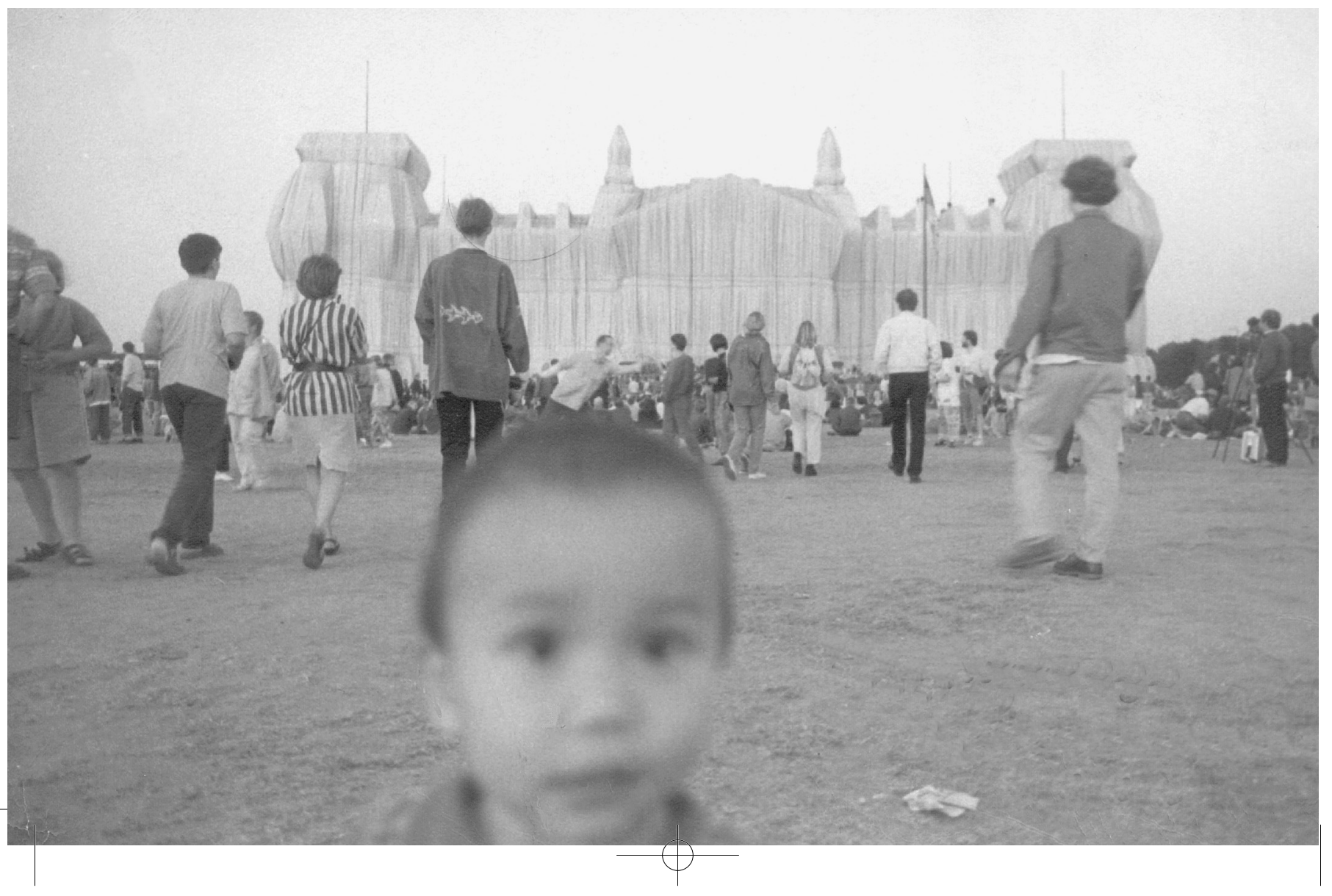




\section{Language}

Without reducing the importance of such socioeconomic, historical, and political analyses to an understanding of the city's reoccupation, I want to turn now to the relationship between language, knowledge, and power and show how these form part of a mechanism to occupy empty space. But first I would like to stress that language, as used here, signifies any system of communication, from the written words of this essay to spoken phrases in the street, from sculpture to architecture, and from urban planning to the cinema.

As Derrida pointed out at the Berlin City Forum, space is not only about geography; space is also symbolic. Indeed, one may argue that empty space is first brought into being, into the realms of knowledge, when it is identified through language. One could take this assertion further and suggest that space, any space, is both formed (in the sense of space being brought into being) and shaped (in the sense that it is given a sense of geometry) in this initial, reflexive act of naming, an act of identification.

The drawing of space with words and images - two primary semiotic systems here-constitutes this space and forms the first and perhaps most important step toward capturing and territorializing what would otherwise remain empty and silent, the space of difference and the space of the other. This constitutes one of the most important features of empty space: it is available for anyone to occupy, irrespective of where they come from, who they are, what they believe, and what they have to say. Graffiti artists inscribing themselves on the Berlin Wall engaged in precisely such an activity when they uttered their cheeky critiques right under the communists' noses. The West German authorities that treated the wall as a kind of no-man's-land happily tolerated such disorderly expressions because it served the overall objectives of the West. The East Germans, on the other hand, kept their side of the wall in a pristine state of white sterility, a blank, clean slate just begging to be written on. This whiteboard of concrete, kept forcibly at bay from the hands of the East German people, allowed the West to invisibly write messages of freedom and democracy in indelible ink. ${ }^{27}$ Language created the space for that other self to come into being, as well as placing a limit around it. Through acts of writing, a sense of belonging (identification with and through writing) could slowly emerge. ${ }^{28}$

Yet if space is left open for occupation by the people, the voice of the state (especially a state that depends, however superficially, on the people to legitimate it) may become fractured into many differing, conflicting, and contradictory voices. This holds especially true if the people are given too much of a say. For this reason the East German authorities would never have allowed Christo to wrap up the Reichstag in the 1970s, when he originally wanted to do it. That act would have freed the meaning of the building — which the communists wished to tie down as a sign of World War II, the tyranny of Hitler, and the fall of German democracy - turning it into a lighter, freewheeling, symbol. Not only did the communists wish to maintain 
the gravity of the symbol, however, but they also desired to keep its fixity. Totalitarian systems seem to prefer maintaining their authorial voice through absolute control over the production of meaning. The iron-fisted rigidity of the Eastern Bloc's signifying system actually allowed the West to develop a more flexible network of signs that did not rely on fixing internal locations for meaning to achieve credibility. By providing the West with itself as a set of fixed referents, the East allowed the West to outmaneuver it.

Yet not only the East German authorities struggled with this dilemma. For if the tolerance of graffiti on the Berlin Wall came to symbolize the difference between two people's ability to express themselves, the graffiti artists' capacity to define and occupy (empty) space in West Berlin lasted only for a limited time. A different story emerged when those same graffiti artists sprayed anti-American slogans during President Reagan's 1987 visit to the Brandenburg Gate. ${ }^{29}$ Now West Berlin authorities hastily remove such writings.

In this essay, I have deliberately tried to conflate the idea of the East (usually thought of as Asia and the Middle East) with the former Soviet Bloc to emphasize the dependence of the West (as distinct from Europe) on identifying an "evil empire" as the straw figure in the binary (linguistic) opposition that gave it its signifying orientation during the Cold War. ${ }^{30}$ Today, however, we must confront that system's failure as part of the bedrock for (our) universal rationalism. This has affected every aspect of Western culture. ${ }^{31}$ As Iain Chambers has pointed out, "we find ourselves employing a language that is always shadowed by loss, an elsewhere, a ghost: the unconscious, an 'other' text, an 'other' voice, an 'other' world; a language that is 'powerfully affected by the foreign tongue.' "32 Other contemporary Western thinkers besides Chambers recognize the role of the other in shaping the languages of the self. These theorists, too, continue struggling to acknowledge and accommodate the other's contribution. Here is how Paul Carter sees it: "It becomes more than ever urgent to develop a framework of thinking that makes the migrant central, not ancillary, to historical processes. We need to disarm the genealogical rhetoric of blood, property, and frontiers and to substitute for it a lateral account of social relations, one that stresses the contingency of all definitions of self and the other, and the necessity always to tread lightly."33

\section{Transition (Osmosis)}

At this point, I must confess to feeling silenced and emptied by these attempts to pursue the task at hand. I especially feel displaced when artists and theorists such as Derrida and Wenders, even Sontag, Chambers, and Carter, talk about invisible spaces - the spaces of the other. I lose my sense of place, that wild, untrammeled, open terrain of difference and being on the outside, even while standing inside. That space to be, in my hitherto empty silence, is recuperated and lost by its translation 


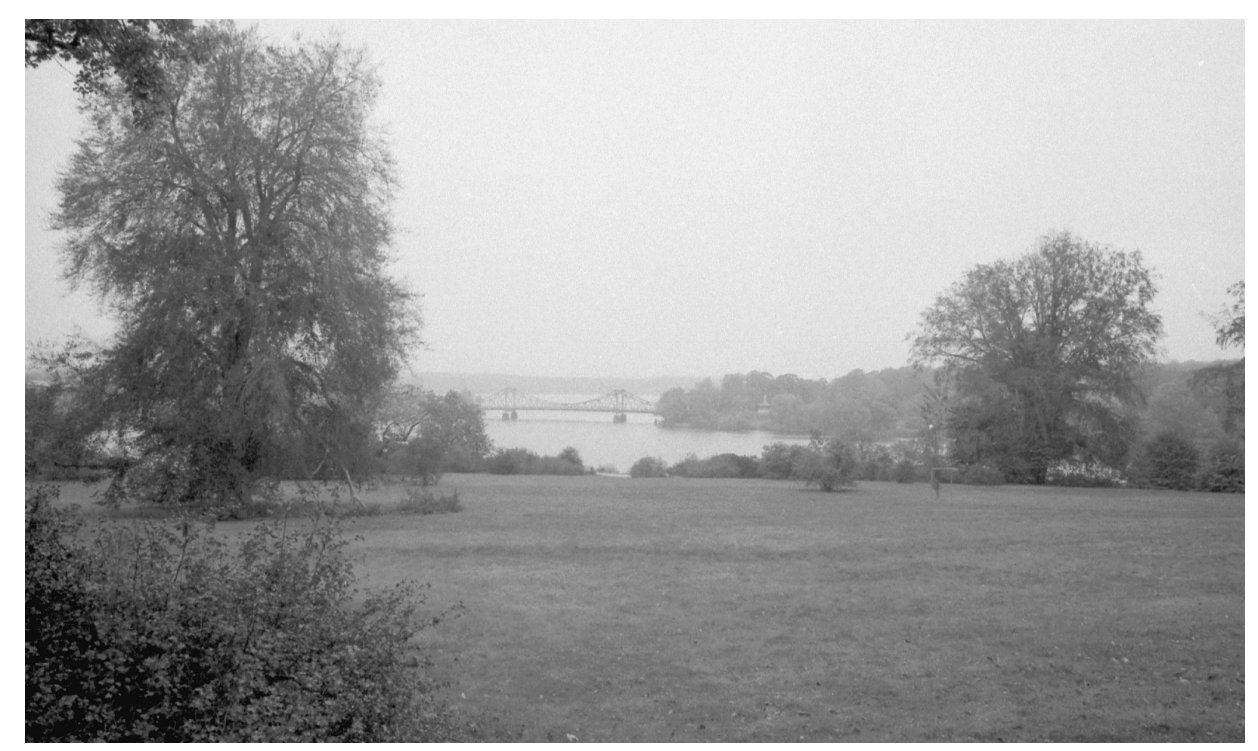

View of Glienicker Bridge as seen from the Volkspark on the shores of the Havel. The Glienicker Bridge was where the East exchanged captured spies and other political prisoners with the West during the Cold War.

into language and transliteration into words and images. But I stand distanced from my own created artifices now, too, these words and these images, as much as from my experience of being an immigrant and tourist.

This new sense of silence and emptiness seems both inexplicable and inescapable, as if the very act of being an author encroaches on the other, whose space remains invisible but no less real. Reduced again to silence, he/she/it is obliged to keep on moving.

Emmanuel Levinas argued that "His" (illeity) exteriority needs to be acknowledged without reduction to the self's language if the other is to be truly honored, negotiated with, and "moved towards." For Levinas, this other remains beyond the phenomena of the self in language, an absoluteness that interrupts the self's linguistic systems, an unmitigated trace or presence beyond self-"being." 34 It is difficult to articulate this point precisely because here we find ourselves at the breakdown of language and at the (emergency) immersion into what we might term the sublime, a moment created when we are forced to cohabit with our "immanent selves," where the contingency of all our possibilities suddenly becomes realizable.

I see connections here to Jean-Luc Nancy's attempts to deal with a body-ofthe-senses. In The Birth of Presence, Nancy suggests the need for a new, impossible corpus, a corpus of discourse (of language as well as of the body) resembling an itinerary or a dictionary. Nancy's corpus is a permeable body, where organs and body parts point toward their emergent openings rather than a totality, openings that then 
signify themselves and "where [their] sense gets lost." 35 This suggests a bank of body parts after a surgical operation, where the body's capacity for discourse (to render or totalize itself whole in language) is abandoned for the sense of feeling, touching, smelling, tasting, and seeing. There is, in Nancy's corpus, an irreducible sense of excess, a body beyond the reach of its own limits, which is to say both beyond and before the self, where sensation floods the body's senses with the recognition of its "saturated totality."36 This extended/distended/attenuated "naked body" exposes senses to senses, and nerves end up on nerves. Nancy's corpus constitutes a glossary for a sensing body, open to all sorts of possibilities left by a surgeon's knife that has opened wounds acting like bioports. ${ }^{37}$

We again arrive at the floating of significance performed by Christo on the Reichstag, an event witnessed by millions, in which a silver-foil wrapping made a weathered and battle-scarred building so buoyant it almost disappeared into the sky. No longer fixed as a sign pointing toward the wounds Hitler and the Second World War inflicted on the German people, Christo's transformation of the building opened up those scars and allowed Germans to reflect on the emergent possibilities the 199os presented. Now, once again, the people could exercise their freedom by just walking around that sealed-off building. Their corpus, those people's wounded polity, still bore the potential (and longing) for their body's healing. But how to do it? By suturing its wounds in yet an(other) act of enclosed solipsism? Or through the connection with other open bodies? Either way, Nancy's open corpus proves a difficult one to live in, as he himself admits. 38

History has repeatedly shown that the state tends toward sealing off such an open body, as in the case of East and West Berlin, even though there must remain some portals, no matter how insignificant, for no human system is capable of independent survival. Berlin's Glienicke Bridge provided one such place that allowed the two former systems to connect. Both sides exchanged their captive spies across that bridge in an act mediating their separate meanings while simultaneously enabling them to negate each other.

On the other hand, many visual artists, writers, and thinkers try to bring an open, wounded body - their art — into existence through language. But as we do, we cannot help but realize that we have to occupy another's space, obliging them to move. Once again, the thing we really longed for-to enter and be a part of - is abandoned, again retreating, back, beyond, behind, beneath. Standing, again defeated, we still do not have what we came looking for. Even the attempt to enter this silent emptiness, something that once seemed a sovereign right, has failed anew. Again and again, we stand on barren, abandoned land, a hollow act made speechless.

What is really interesting about writing or making art is not that the voice of the author, any author, your ego-I or mine, is incapable of speaking for this, that, or any other. Or even that such attempts to speak the others' truths (or art) render our 
thoughts shallow utterances, simple, solipsistic reflections of and on the self (masquerading as the other). Such problems have consumed the minds of many, including Derrida and Gayatri Spivak. ${ }^{37}$

I want to explore the losing of the space once occupied by the self as other living in the self, like standing on the outside while also standing in. This magical disappearing-reappearing act seems partly to hinge on culture and partly on language. But in continuing to exist in different cultures and languages, one sometimes becomes aware, glimpses for a moment, that the very things once promised by language and culture, our selves and others realized in artifices, are lost again in lasting silence.

\section{Emptiness}

Not everyone agrees that the self and the other are linked in silence. Homi Bhabha, for example, suggests that one can overcome the loss of the other through parody, by cloaking it in the language of the self half-jokingly, in mimicry of the center. ${ }^{40}$ For Bhabha, the act of faking a semiosis of the self, acting like a naughty shadow if you like, distorts the self and renders the other visible. But that seems like an extreme

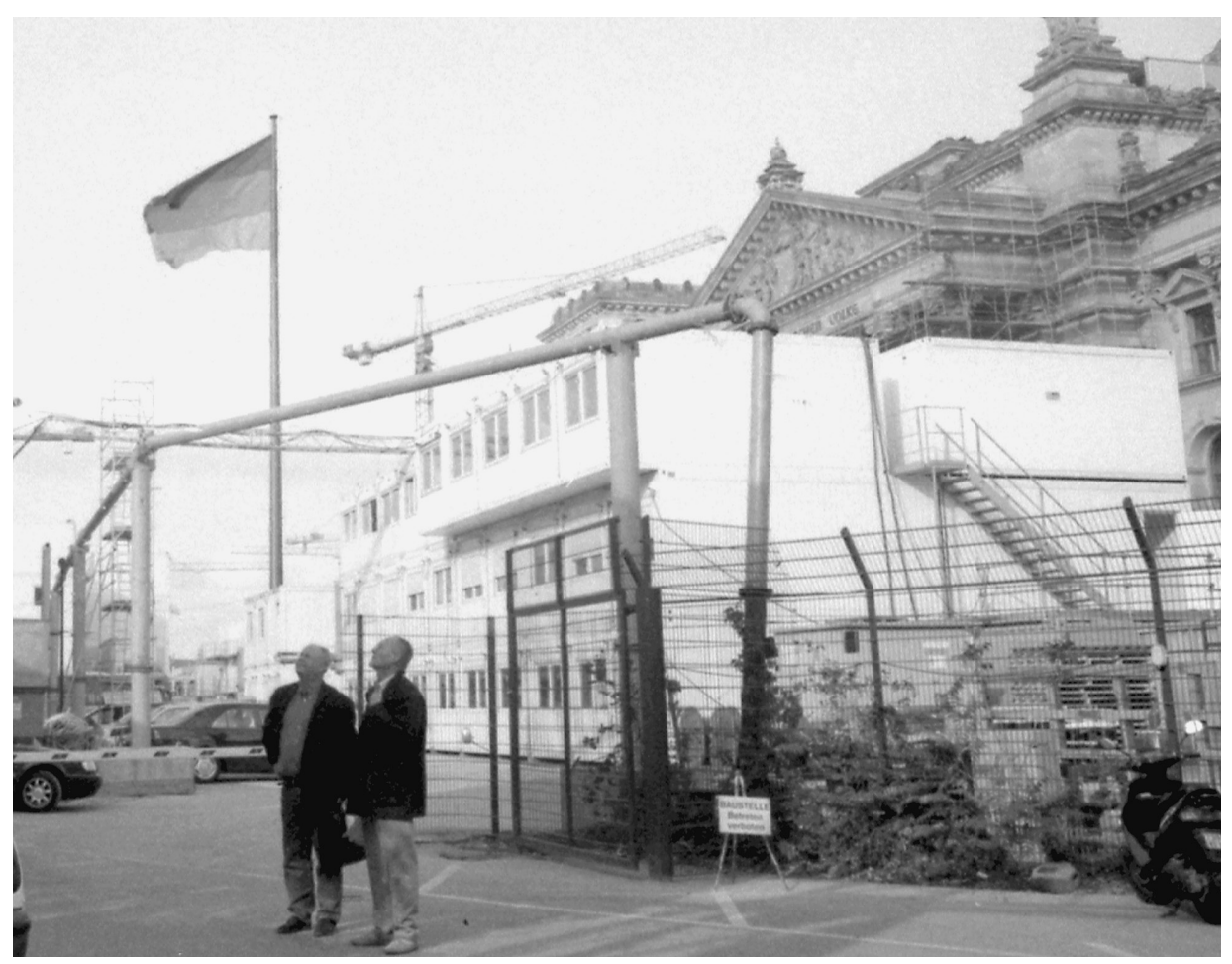

A behind the scenes view of the reconstruction of the Reichstag in 1998. This figure was taken only months before the German Parliament was to again take its seat in Berlin. Yet the Reichstag is a symbol of mixed meanings, the house where the will of the German people was excercised, as well as the place where German democracy was curtailed and overthrown. 
position, eccentric and freakish, and one that undermines the integrity of both the self and the other. It also avoids the problem of the many-sided bodies coexisting in one and many places simultaneously. Bhabha's formulation may prove appropriate to a non-European other coming from beyond a European self, but I favor Tzvetan Todorov's position, which he came to on returning to his native Bulgaria after living in Parisian exile for eighteen years. Todorov argued, "My double belonging only produces one result: in my own eyes, it taints each of my two discourses with inauthenticity, since each can correspond but to half of who I am; yet I am indeed double. I thus once again confine myself to an oppressive silence." 41

Now, can we find something more compelling in Todorov's silence, a resistance that stays beyond both time and space, beyond the language of oppression and discourses of capture? Is the other-self more real in emptiness, in silence, and in loss? Would not it have been better if the German parliament had remained seated elsewhere, leaving the Reichstag, a tragic symbol of mixed and (now) empty meanings, to stand in silence? In an essay about the emptiness in the word paintings of Ilya Kabakov, Mikhail Epstein suggests an answer:

Art . . . becomes a rite of circumnavigating emptiness, of slow, cautious, and deliberate capitulation. It is [Mikhail] Kutuzov's, not Napoleon's tactics of encountering emptiness: instead of attacking it with militant cultural projects, one retreats, ceding . . . where emptiness least expects to find a place-at the heart of the artist's creation. In order to prevent emptiness from swallowing up this creation, depriving it of meaning from the outside, it is made to curl up inside it, like a quiet, well-fed, docile wild animal in a cage. ${ }^{42}$

Well, is that all that there is left the work of art in the age of global capitalism? Is a caged-up silent terror, that wild and cunning beast at the heart of creation, still the center of our culture?43 If so, where does that lead us now? And should such mythologizing explanations still satisfy us? Kutuzov's technique, as successful as it might prove in avoiding capture, still leaves us, as self and other, in a (linguistic) conundrum with nothing apparent left, logically, but to remain in separation, as if we are at war.

In thinking further about this problem, and I am thinking out aloud right now, at least part of the dilemma seems to be one of situation, as Sartre might have replied, of discerning when to withhold or withdraw into/beyond one's location, and when to uncloak and become an other-self. ${ }^{44}$ Because, more than just a connoisseur, the flâneur finds the animal in its cage not only picturesque but also wants to engage it. Paradoxically then, the German parliament may have made the right decision to reoccupy the Reichstag and confront the questions it raises head-on. Danger remains, however, whether we leave that animal locked up or open up the door.

Conventionally, the city resolved this problem by deferring special proper- 
ties, for example, when it grants the migrant the mantle of the citizen. This solution, however, reproduces the mechanisms of capture and colonization by reinstating boundaries between ourselves and others. Are, as Ernesto Laclau suggested, other language games possible, then, games that seek to move through empty spaces without filling them with a rigid self? 45 What we need is a kind of multiple epistemology/epistemologies that allows ever emerging ontologies to dissect both time and space by constantly entering unknown time-spaces that remain logically (and linguistically) irreconcilable. What is missing, it seems to me, is an extrasensory, out-ofbody experience, a sense of that other-self — the body of a traveler - always moving within/without the city. Must those travelers remain contained and invisible, as in a Trojan horse, even if, on the margin, they are reduced, except in silence? Is this a silence of respect?

If we conclude, as onetime Stasi boss Markus Wolf conceded, that the erection of the Berlin Wall was as much a sign of failure and defeat as it was a sign of force and (attempted) containment of "the people," then we must also recognize that closing the city gates (as does the fortress Europe) on those unwanted migrants shows that we have yet to learn from history. ${ }^{46}$ For if we really want out of the cage and to bridge the gap between our selves and our imprisoned others, we must reconcile to being with them. The question of cohabitation still haunts us then.

\section{Conclusion}

Perhaps the greatest legacy we have inherited from the moderns is an inescapable sense of exile, an exile not just from our physical homelands, but also from the home that is ourselves. As postmoderns we still know this condition, although it does not seem as strong as the alienation our parents and grandparents might have felt. Unlike the sense of total separation derived from their migrant duality, our feeling is merely one of displacement. We feel like tourists today, decentered, disjointed subjects, somewhat incoherent and unintelligible, like drug-fucked addicts going through cultural withdrawal.

Berliners know such feelings. But at the same time, maybe they do not, or maybe they have forgotten. Nevertheless, I think it is important to acknowledge that Berlin today has come a long way from the war-ravaged tyrant city of the twentieth century. The beginning of the end came when real living socialism tried to contain and direct the people's imagination. Yet in spite of all intention, the vacuum at the Berlin Wall still gave people space to roam and soar and climb, once more, over the strictures of the everyday.

On the other hand, we could say that the West's greatest "success" lies in its rapacious capacity to occupy and exploit free and empty space. But where is that now leading to? Is there still space for an other-self? As capitalism drives us harder into the immediacy of the moment, have we succumbed to the desire of the present 
138 Radical History Review

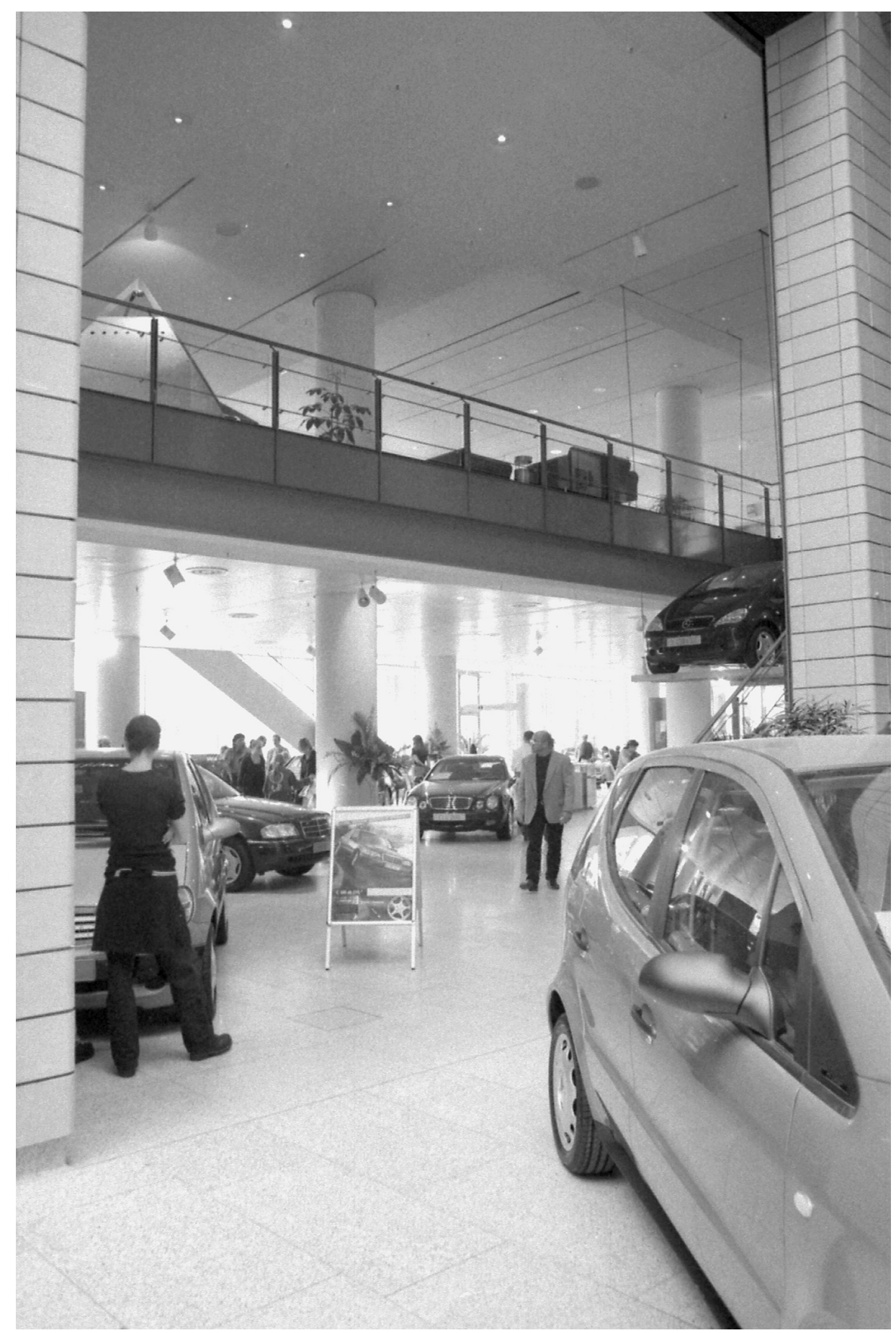

Car showroom, Potsdamerplatz, 1998. Dreaming of freedom or base material aspirations? 
without regard, as Derrida might have put it, for others-spaces deferred to otherstimes? Can we still see the invisible beneath the drying concrete on the holes within the heart?

Berlin provides a somewhat glossy reminder of where Western culture has come from and where it might head to. Its peaceful scenes of civic reconstruction might yet provide us with a moment of new creation, symbolic as well as geographical. But just as surely as the chiefs of capital seek out ever new and unexploited places, they will bind them up with money, the language of our power, and lock them up behind the glassed-in walls of sanitized shopping arcades. This literally happened at Potsdamerplatz, where the empty space that once signified a longing place for freedom has today become a shopping mall. The exclusive showrooms inside now underwrite dreams of freedom with credit cards.

Now, yet again, another timely reminder: "the city" must still fulfill its founding task - to allow the people to actualize their lives, not just as tourists, migrants, or citizens, but simply as "the people"- for that is the meaning of a metropolis. Is there still room, one has to ask, for that strange, mystical power, the source of our creative energy (name it what you want- "God," if you like) 47 to surge us forth and point toward a yonder, a beyond-dot-com? Or are we about to find that, in the end, only ads could ever prime our dreams?

\section{Notes}

1. Lewis Mumford, The City in History: Its Origins, Its Transformations, Its Prospects (Middlesex, U.K.: Penguin, 1974).

2. See also the description of Potsdamerplatz during the twentieth century in Peter Conrad,

Modern Time, Modern Places: Life and Art in the Twentieth Century (London: Thames and Hudson, 1998), 62-64.

3. For other views on life in Berlin and Germany during the Cold War, see Charles E. McClelland and Steven P. Scher, eds., Postwar German Culture: An Anthology (New York: Dutton, 1974); Jeremy Isaacs and Taylor Downing, Cold War (London: Bantam, 1998); and Rob Burns, ed., German Cultural Studies: An Introduction (Oxford: Oxford University Press, 1995). For a more general sociology of major developments in Germany during the nineteenth and twentieth centuries, see Norbert Elias, The Germans (Cambridge: Polity, 1997).

4. Karen Jaehne, “Angel Eyes: Wenders Soars," Film Comment 24.3 (1988): 19-20.

5. See the photo caption for the image of Kurfürstendamm in Alexandra Richie, Faust's Metropolis: A History of Berlin (London: Harper Collins 1999), 852-53.

6. For some contemporary views of the postmodern city, see Jonathan Crary et al., eds., Zone 1/2: City (New York: Urzone, 1986). See also Jonathan Raban, Soft City (London: Harvill, 1998).

7. Markus Wolf, Man without a Face: The Memoirs of a Spymaster (London: Cape, 1997), 114. 
8. For analytical surveys of Wenders's films, see Roger F. Cook and Gerd Gemünden, eds., The Cinema of Wim Wenders: Image, Narrative, and the Postmodern Condition (Detroit: Wayne State University Press, 1997); Thomas Elsaesser, New German Cinema: A History (London: Macmillan, 1994); Kathe Geist, The Cinema of Wim Wenders: From Paris, France to Paris, Texas (Ann Arbor, MI: UMI Research Press, 1988); and Robert Phillip Kolker and Peter Beicken, The Films of Wim Wenders: Cinema as Vision and Desire (Cambridge: Cambridge University Press, 1993).

9. Wim Wenders, quoted in Jacques Derrida, Kurt Forster, and Wim Wenders, "The Berlin City Forum Symposium," Architectural Design 62 (1992): 53.

10. Jacques Derrida, quoted in Derrida, Forster, and Wenders, "The Berlin City Forum," 45, 50, 51 .

11. Brian Ladd, The Ghosts of Berlin: Confronting German History in the Urban Landscape (Chicago: University of Chicago Press, 1997), 7-39.

12. Jürgen Habermas, The Berlin Republic (Cambridge: Polity, 1998), 17-40.

13. "Topographies of Terror" is a permanent exhibition at the rear of the Martin Gropius Bau that was the SS's Headquarters during World War II. The exhibition is held in an excavated series of underground chambers that the SS used to torture and kill their victims, who included not only Jews, gays, and other deviants, but also German nationals unsmpathetic to the Facsists, such as Communists, and other sympathisers.

14. Ladd, Ghosts of Berlin, 18.

15. Dick Hebdige, “Guilt Trips: Coming Up against the Wall," Art and Text 36 (1990): 52-69.

16. Michel de Certeau, The Practice of Everyday Life (Berkeley: University of California Press, 1988), 99 .

17. Susan Sontag, quoted in John Urry, The Tourist Gaze: Leisure and Travel in Contemporary Societies (London: Sage, 1990), 138. See also Walter Benjamin, Charles Baudelaire: A Lyric Poet in the Era of High Capitalism, trans. Harry Zohn (London: New Left Books, 1973). For an analysis of walking in the city, see de Certeau, Practice of Everyday Life, 91-130.

18. Benjamin, Charles Baudelaire, 35-54.

19. de Certeau, Practice of Everyday Life, 91.

20. For an exposition of the classical technique of relating space and memory, see Frances A. Yates, The Art of Memory (London: Pimlico, 1992), 17-41.

21. Wim Wenders, The Logic of Images (London: Faber and Faber, 1992), 98.

22. For an analysis of Margaret Thatcher's economic rationalist policies on the un(der)employed, see Will Hutton, The State to Come (London: Vintage, 1997), 35-41.

23. Howard Caygill, "The Futures of Berlin's Potsdamer Platz," in The Limits of Globalization, ed. A. Scott (Routledge: London, 1997), 25-54.

24. In Wings of Desire, Homer is the storyteller, a character who remembers Berlin in the 1920 s and goes looking for Potsdamerplatz among the ruins in the shadows of the Berlin Wall.

25. Wim Wenders, The Act of Seeing (London: Faber and Faber, 1997), 104-5.

26. Caygill, "The Futures," 42.

27. For a discussion of the differences between officially sanctioned writing (such as advertising) and unofficial writings (such as graffiti), see Tim Cresswell, "Night Discourse," in Images of the Street: Planning, Identity, and Control in Public Space, ed. Nicholas R. Fyfe (London: Routledge, 1998), 268-74. 
28. See the treatise on nomadology, the refrain, territorialization and deterritorialization in Gilles Deleuze and Félix Guattari, A Thousand Plateaus: Capitalism and Schizophrenia, trans. Brian Masumi (London: Athlone, 1988), 299-302, 312, 317, 321, 347-48.

29. Ladd, Ghosts of Berlin, 28.

30. See also Edward Said, Orientalism (New York: Vintage, 1978).

31. There are trends that suggest that China is being cajoled into this role, something that would certainly restore the linguistic system of the West but would prove disastrous for global politics.

32. Iain Chambers, Migrancy, Culture, Identity (London: Routledge, 1994), 4. There are many useful ideas in Chambers's first chapter, “An Impossible Homecoming," where, in addition to his own thoughts, the author also refers to Rudolf Pannwitz whom Walter Benjamin quoted.

33. Paul Carter, quoted in Chambers, Migrancy, Culture, Identity, 5 .

34. Emmanuel Levinas, "The Trace of the Other," in Deconstruction in Context: Literature and Philosophy, ed. Mark C. Taylor (Chicago: University of Chicago Press, 1986), 345-59 (especially $356-59$ ).

35. Jean-Luc Nancy, The Birth of Presence (Stanford, CA: Stanford University Press, 1993), 197. Pages 189-207 prove useful.

36. Ibid., 206.

37. I refer to David Cronenberg's eXistenZ (1999), a film in which people have computer ports inserted at the bottom of their spines so that they can participate with other living subjects in a game that combines reality with the simulated possibilities generated by the game's codes and rules.

38. Nancy, Birth of Presence, 189.

39. See the entry on "Gayatri Chakravorty Spivak," in The Icon Critical Dictionary of Postmodern Thought, ed. Stuart Sim (Cambridge: Icon, 1998), 362.

40. Refer to the entry on "Subaltern Theory" in Sim, Icon Critical Dictionary, 366.

41. Tzvetan Todorov, "Bilingualism, Dialogism, and Schizophrenia," New Formations 17 (1992): 23.

42. Mikhail Epstein, Alexander A. Genis, Slobodanka M. Vladiv-Glover, Russian Postmodernism: New Perspectives on Post-Soviet Culture (New York: Berghahn, 1999), 326. Thanks to Slobodanka Vladiv-Glover for introducing me to Epstein's work.

43. For more on art as a sign system where meaning as an operative language, see Alphonso Lingis, "Translator's Preface," in The Visible and the Invisible by Maurice Merleau-Ponty, ed. Claude Lefort (Evanston, IL: Northwestern University Press, 1968), i-liii.

44. William L. McBride, Sartre’s Political Theory (Bloomington: Indiana University Press, 1991).

45. Ernesto Laclau has developed an impressively cogent argument for the preservation of progressive language games based on "universalism" as a "contingent historical product" in the concluding paragraphs of his Emancipation(s) (New York: Verso/New Left Books, 1996), 122-23. Laclau rejects the use of terms like God and Nature on the grounds that they discourage people from becoming "strong poets" — that is to say, such terms, to him, reduce people's capacity to act out of their own volition. Instead, they tend to defer their creativity extrinsically. I see similarities between the idea of "strong poets" and Heinz von Foerster's notions of the self-creating "autopoesis" of "non-trivial machines." Foerster ascribes the term autopoesis to the Chilean neurophilosophers F. Varela, U. Maturana, and 
142 Radical History Review

G. Uribe. See Lynn Segal, The Dream of Reality: Heinze von Foerster's Constructivism (New York: Norton, 1986), 127-28. In contrast to Laclau, I use multiple epistemologies and emergent ontologies (similar, perhaps, to the idea of ontochronology found in Heidegger) because I am not completely comfortable with the word universalism. I also remain committed to ideas of multiculturalisms as a recognition of multiple, coexistent languages. I do concede, however, that Laclau speaks about (multiple) language games, so perhaps this is more an argument over our choice of words.

46. Wolf, Man without a Face, 98-122.

47. I retain the use of the word God because I want to suggest that there will almost certainly always be something inexplicable about the universe that the human mind will never, can never, come to know and understand within or through language. Recognizing the limits of human language means, first and foremost, that we must remember to remain humble about ourselves, our sense of place, and the faith we have in our knowledge and understanding in the face of the universe. 
Copyright $\odot 2002$ EBSCO Publishing 